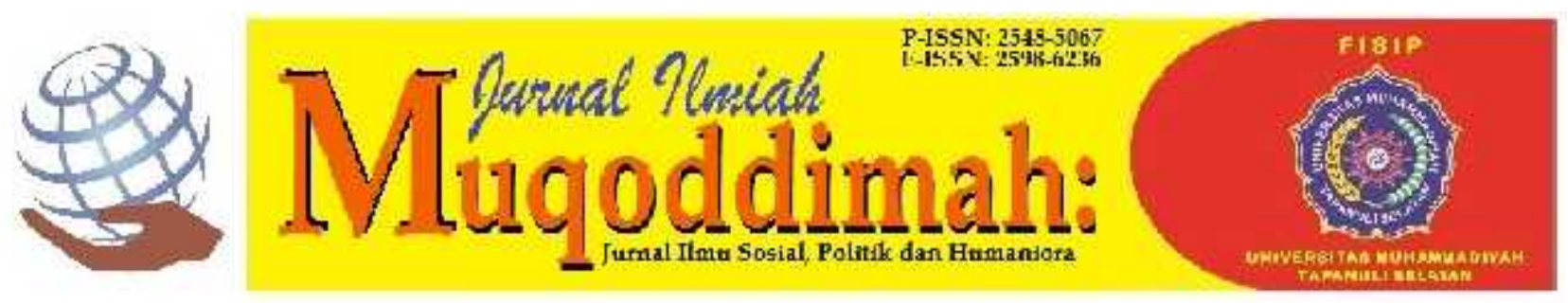

\title{
Partisipasi Politik Mahasiswa Asal Aceh di Kota Semarang
}

\author{
Syahrur Ramadhi ${ }^{1),}$ Laila Kholid Alfirdaus ${ }^{2)}$
}

\author{
Magister IImu Politik, Universitas Diponegoro \\ JI. Imam Bardjo, SH, No. 1, Semarang, Jawa Tengah, Indonesia \\ syahrur123@gmail.com ${ }^{1)}$ \\ alfirdaus_laila@yahoo.com²)
}

\begin{abstract}
Abstrak
Mahsiswa Aceh sebagai kelompok intelektual muda memiliki keinginan kuat dalam berkontribusi dalam meningkatkan kemajuan bangsa melalui pesta demokrasi. Partisipasi politik menjadi titik awal mahasiswa untuk melakukan perubahan dengan menyalurkan suara dalam pemilu, sehingga mendorong antusiasme dan perhatian lebih dalam pemilu. Namun ada mahasiswa yang memutuskan tidak menyalurkan suaranya pada pemilu. Tujuan penelitian ini, mendeskripsikan partisipasi politik dan faktor yang mempengaruhi partisipasi politik mahasiswa asal Aceh di Kota Semarang pada Pemilihan Presiden Tahun 2019. Metode yang digunakan diskriptif kualitatif dengan 17 narasumber yang tergabung dalam Ikatan Pelajar Aceh Semarang (IPAS). Teknik pengambilan sampel menggunakan teknik purposive sampling. Hasil peneltian menunjukan partisipasi politik mahasiswa Aceh terjalin baik, dengan tingginya perbincangan mengenai pemilu yang dijalani dalam kehidupan asrama. Tipologi pemilih tergolong kedalam tipe relasional dan kritis yang mampu menilai berdasarkan fakta lapangan. Faktor yang mempengaruhi partisipasi ada tiga faktor kongnitif, kandidat dan orang tua. Faktor hambatan terjadi karena persyaratan admistrasi yang membutuhkan waktu lebih dalam mengurusnya.
\end{abstract}

Keywords : Partisipasi Politik, Mahasiswa, Pemilihan Umum, Pemilihan Presiden

\begin{abstract}
The Students of Aceh as a group of young intellectuals have a strong interest in supporting the improvement of the nation through the party of democracy. Political participation is the starting point for students to make changes by channeling votes in the election, thereby encouraging enthusiasm and paying more attention in the election. Students who decide not to cast their votes in the election. The purpose of this study is to describe political participation and the factors affecting the participation of students from Aceh in Semarang City in the 2019 Presidential Election. The method used is descriptive qualitative with 17 speakers who are members of the Aceh Aceh Student Association (IPAS). The sampling technique uses a purposive sampling technique. The results of the research show that the political participation of Acehnese students is well established, with a high level of participation in the elections held in the life of the asrama. The typology of voters is classified into a relational and critical type that is able to judge based on field facts. There are three factors that influence participation, the candidate, and the parents. A must factor that occurs due to administrative requirements that require more time in handling.
\end{abstract}

Keywords: Political Participation, Students, General Elections, Presidential Elections 


\section{PENDAHULUAN}

Mahasiswa merupakan fase usia yang dinamis, mempunyai keinginan kuat untuk mencoba pengalaman baru, menjalin hubungan sosial dan menyukai yang bersifat praktis. Peran mahasiswa sebagai kelompok pelajar menjadi pilar demokrasi yang mampu meningkatan partisipasi dengan menggunakan hak suara dalam pemilihan umum. Mahasiswa yang memiliki sifat dinamis, kreatif, responsif dan peka terhadap problema-problema kemasyarakatan, perkembangan intelektual membangunkan berbagai fungsi psikis, rasa ingin tahu sehingga tumbuh dorongan yang kuat untuk mencari ilmu pengetahuan dan pengalaman baru (Yusuf, 2002:184). Artinya mahasiswa memiliki pemahaman lebih mengenai kehidupan berdemokrasi dibanding kelompok lain. Namun kondisi yang jauh dari tempat tinggal tidak menurunkan minat dalam menyalurkan suara dalam pemilu salah satunya mahasiswa asal Aceh. UndangUndang Republik Indonesia Nomor 3 Tahun 1999 Tentang Pemilihan Umum pasal 6 berbunyi "Pemberian suara dalam pemilihan umum adalah hak setiap warga negara yang memenuhi syarat untuk memilih". Artinya setiap warga negara memiliki hak yang sama dalam menyalurkan suara.

Mahasiswa Aceh yang sebagain besar tergabung dalam Ikatan Pelajar Aceh Semarang (IPAS) memiliki partispasi dalam pemilihan presiden tahun 2019 yang ditandai dengan tingginya minat mahasiswa asal Aceh yang mengurus form C5 sehingga dapat memilih pada TPS terdekat dari tempatnya berdomisili di kota Semarang. Berdasarkan data Komisi Pemiliah Umum (KPU) pada pemilihan presiden berikut perbandingan hasil pemilihan warga dan mahasiswa di Kota semarang:

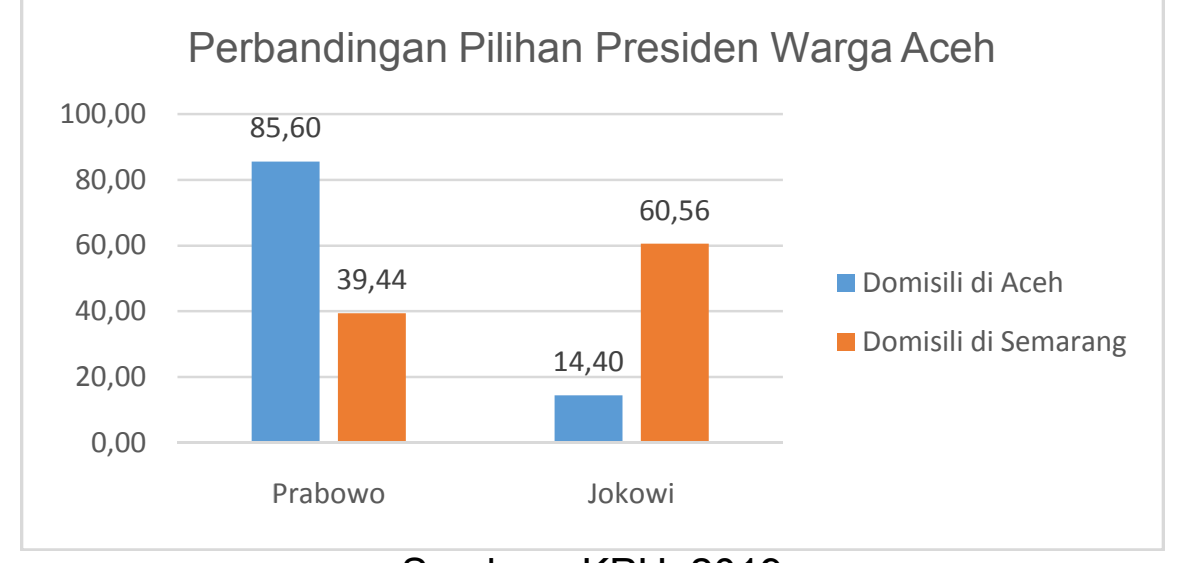

Sumber : KPU, 2019

Berdasarkan data diatas, perbedaan antara pilihan presiden yang berdomisili di Aceh pilihan presidennya $85,60 \%$ adalah pada calon presiden Prabowo Subiyanto, dan hanya $14,40 \%$ yang memilih calon presiden Joko Widodo. Sedangkan pada mahasiswa Aceh yang memilih di kota Semarang, didapatkan bahwa terdapat pilihan yang sangat berbeda dengan warga Aceh pada daerahnya sendiri yaitu 60,56\% memilih Joko Widodo sedangkan hanya $39,46 \%$ memilih Prabowo Subiyanto. Artinya mahasiswa Aceh memiliki antusiasme tinggi dalam pemilihan. Perbedaan pilihan tersebut sangat dipengaruhi faktor, Lingkungan dan kebudayaan, di Aceh pilihan sangat dipengaruhi toko ulama, sedangkan di Semarang sendiri lebih pada pandangan politik dan pola pikir aktor. 
KPU sebagai lembaga bertanggung jawab atas terselenggaranya pemilihan umum di Indonesia telah memberikan sosialisasi mengenai Pemilu melalui media massa dengan selalu mengingatkan warga untuk menggunakan hak pilihnya dalam Pemilu terutama bagi pemilih pemula. Sosialisasi tersebut dinilai efektif menarik pemilih pemulah terutama kalangan mahasiswa. Menurut Liandi (2016) yang meneliti mengenai pemilu dan partisipasi politik masyarakat di kabupaten Minahasa menyatakan bahwa tingkat partisipasi politik masyarakat sangat dinamis dan dipengaruhi motiviasi yang didasari faktor transaksi dan unsur kedekatan secara emosional. Visi dan misi calon bukan merupakan ukuran dalam memilih dan tidak memberikan suara karena masalahmasalah teknis mulai tidak terdaftar DPT dan informasi mengenai pemilu. Berbeda dengan partisipasi pemilih pemulah yang diteliti Perangin-angin dan Zainal (2018) dari wawancara mendalam dengan 63 mahasiswa yang dipilih secara sengaja di 3 kota besar; Bandung, Jakarta, dan Surabaya, menunjukkan media sosial telah digunakan secara massif oleh para pemilih pemula karena melalui media sosial mereka dapat berinteraksi dan berkomunikasi tanpa memerlukan persiapan fisik maupun keharusan untuk memperlihatkan atribut kepribadian secara terbuka. Media sosial berkontribusi dalam memberikan wawasan mengenai partisipasi politik pemilih pemula di media sosial dengan harapan bisa memotivasi agar pengguna media sosial juga berusaha untuk bisa melek politik. Penelitian ini menarik melihat bagaimana partisipasi politik mahasiswa asal Aceh dan faktor yang mempengaruhi partisipasi politik mahasiswa asal Aceh di Kota Semarang pada Pemilihan Presiden Tahun 2019?. Tujuan penelitian ini mendeskripsikan dan menganalisis partisipasi politik dan faktor yang mempengaruhi partisipasi politik mahasiswa asal Aceh di Kota Semarang pada Pemilihan Presiden Tahun 2019.

Terdapat beberapa faktor yang mempengaruhi perilaku politik individu dan aktor politik yang menjadi kombinasi dari ketiga model perilaku pemilih. Pertama adalah lingkungan sosial politik yang tidak langsung. Kedua, lingkungan sosial politik yang langsung mempengaruhi. Ketiga, adalah struktur kepribadian yang tercermin dalam sikap individu. Menurut Nursal (2004:54) pendekatan perilaku pemilih terdapat empat model pendekatan untuk menjelaskan sejauh mana ketiga model tersebut mempengaruhi atau berperan atas pilihan seorang pemilih. Keempat model pendekatan tersebut adalah model sosiologis (karakteristik sosial dan pengelompokan sosial usia, jenis kelamin, agama, pekerjaan, latar belakang keluarga, kegiatan-kegiatan dalam kelompok formal dan informal), model psikologis (menyangkut persepsi pemilih atau partai-partai politik yang ada atau adanya korelasi atau keterikatan emosional pemilih terhadap partai politik), dan model pilihan rasional atau ekonomi politik (perhitungan untung dan rugi secara pribadi jikalau seseorang memilih sebuah partai politik), dan pendekatan Domain kognitif (Pendekatan Marketing) (Harahap, 2016: 5-6). Sedangkan faktor-faktor yang mempengaruhi perilaku pemilih meliputi. Pertama, Social imagery atau citra sosial ( pengelompokkan sosial) merupakan citra kandidat atau partai dalam pikiran pemilih mengenai "berada" di dalam kelompok sosial atau tergolong sebagai apa sebuah partai atau kandidat politik. Kedua, kandidat (candidate personality) mengacu pada sifat-siafat pribadi penting yang dianggap sebagai karakter kandidat. Beberapa sifat yang merupakan candidate personality adalah artikulatif, welas asih, stabil, energik, jujur, tegar, dan sebagainya. Ketiga, Peristiwa-peristiwa tertentu (situational contingency) yang terbagi menjadi current events dan personal events. Current events 
mengacu pada himpunan peristiwa, isu, dan kebijakan yang berkemang menjelang dan selama kampanye. Current events meliputi masalah domestik dan masalah luar negeri. Masalah domestik misalnya tingkat inflasi, prediksi ekonomi, gerakan separatis, ancaman keamanan, korupsi, dan sebagainya. Masalah luar negeri misalnya perang antar negara-negara tetangga mempunyai pengaruh baik langsung maupun tidak langsung kepada para pemilih. Personal events mengacu kepada kehidupan pribadi dan peristiwa yang pernah dialami secara pribadi oleh seorang kandidat, misalnya skandal bisnis, skandal seks, menjadi tokoh perjuangan pada masa tertentu, dan sebagainya. Keempat, Isu dan kebijakan politik (political issues) menyangkut resentasikan kebijakan atau program yang dijanjikan oleh partai atau kandidat politik jika menang Pemilu. Kelima, Faktor-faktor epistemic (epistemic issues) adalah isu-isu pemilihan yang spesifik yang dapat memicu keinginan para pemilih mengenai hal-hal baru (Newman \& Sheth, 1985:178-180).

Perilaku pemilih seseorang dapat dipengaruhi oleh sikap seseorang yang terbentuk melalui sosialisasi panjang yang dari latar belakang keluarga, maupun lingkup pekerjaan, agama, atau kegiatan-kegiatan dalam kelompok formal dan informal. Sikap seseorang tersebut akan meberikan pemahaman terhadap isu kebijakan dan kandidat. Sikap politik seseorang terhadap objek politik yang terwujud dalam tindakan atau aktivitas politik merupakan perilaku politik seseorang. Menurut Sastroatmojo (1995: 8) perilaku politik adalah tindakan yang dilakukan oleh pemerintah ataupun masyarakat berkaitan dengan tujuan dari suatu masyarakat, kebijakan untuk mencapai suatu tujuan, serta sistem kekuasaan yang memungkinkan adanya suatu otoritas untuk mengatur kehidupan masyarakat kearah pencapain tujuan tersebut (Mas'udi, Qodarsasi, \& Dewi, 2018:173).

Partisipasi politik menurut Ramlan Surbakti (1999:54) adalah kegiatan warga negara yang bertujuan untuk mempengaruhi pengambilan keputusan politik. Partisipasi politik dilakukan orang dalam posisinya sebagai warganegara, bukan politikus ataupun pegawai negeri. Sifat partisipasi politik ini adalah sukarela, bukan dimobilisasi oleh negara ataupun partai yang berkuasa. Ruang bagi partisipasi politik adalah sistem politik. Sistem politik memiliki pengaruh untuk menuai perbedaan dalam pola partisipasi politik Warga negaranya. Kebalikan dari partisipasi adalah apati (apathy) dimana ada kelompok masyarakat yang sama sekali tidak melibatkan diri dalam kegiatan politik (Bisri, 2011).

Sebab-sebab adanya partisipasi politik yang luas yaitu (Myron Weiner yang dikutip Mas'oed,: Pertama, modernisasi dalam segala bidang kehidupan yang menyebabkan masyakat masih banyak menuntut untuk ikut dalam kekuasaan politik. Kedua, perubahan-perubahan struktur-struktur kelas sosial, masalah siapa yang berhak berpartisipasi dalam pembuatan keputusan politik menjadi penting mengakibatkan perubahan dalam pola partisipasi politik. Ketiga, pengaruh kaum intelektual dan komunikasi masa modern, ide demokratisasi partisipasi telah meyebar ke bangsabangsa baru sebelum mereka mengembangkan modernisasi dan industrialisasi yang cukup matang. Keempat, konflik antar kelompok pemimpin politik, jika timbul konflik antar elit maka yang dicari adalah dukungan rakyat maka terjadi perjuangan kelas menengah melawan aristrokrasi sehingga menarik kaum buruh dan membantu memperluas hak pilih rakyat. Kelima, keterlibatan pemerintah yang meluas dalam uruusan sosial, ekonomi, dan kebudayaan (Rio dkk, 2014). Tinggi rendahnya partisipasi 
masarakat ditentukan pada kepercayaan masarakat pemerintah yang mendorong masyarakat aktif dalam menyuarakan suarannya dalam pemilu.

\section{METODE}

Penelitian ini menggunakan pendekatan deskriptif kualitatif, pendekatan kualitatif di definisikan sebagai suatu proses yang mencoba untuk mendapatkan pemahaman yang lebih baik mengenai kompleksitas yang ada dalam interaksi manusia. Definisi ini menunjukkan beberapa kata kunci dalam penelitian kualitatif, yaitu: proses, pemahaman, kompleksitas, interaksi, dan manusia. Sasaran utama pada penelitian deskriptif kualitatif adalah manusia karena manusia sumber masalah dan sekaligus penyelesai masalah (Sarwono, 2006:194).

Subjek dalam penelitian ini adalah mahasiswa asal Aceh yang saat ini sedang menempuh pendidikan di kota Semarang dengan jumlah 17 narasumber. Teknik pengambilan sampel dalam penelitian ini akan menggunakan teknik purposive sampling, yaitu pengambilan sampel dengan kriteria tertentu. Kriteria yang diambil dalam penelitian ini adalah mahasiswa asal Aceh yang saat ini masih aktif menempuh pendidikan baik S1 dan S2 yang saat ini tinggal di Asrama Aceh jalan Iwenesari, Banjarsari, kecamatan Tembalang.

\section{HASIL DAN PEMBAHASAN}

\section{Partisipasi Politik Mahasiswa Asal Aceh Di Kota Semarang}

Partisipasi politik adalah suatu kegiatan dari warga negara baik secara langsung maupun tidak langsung (tidak sengaja) terkait dengan kebijakan-kebijakan pemerintah dapat dilakukan oleh indvidu-individu maupun kelompok secara spontan maupun dimobilisasi ( Sitepu, 2012 dalam Mas'udi et al., 2018:59). Pemilihan umum merupakan salah satu sarana masyarakat terlibat dalam memutuskan untuk kebijakan. Tipologi pemilih mahasiswa pada Pemilihan umum serentak 2019 yang merupakan kontestasi politik melibatkan seluruh rakyat Indonesia untuk dapat menyalurkan hak suaranya, baik dari tingkatan nasional yaitu pemilihan presiden dan wakil presiden, DPR-RI, dan DPD, baik tingkatan provinsi yaitu DPRD-Provinsi, sampai pada tingkatan daerah berupa pemilihan anggota legislatif DPRD Kabupaten/kota. Mahasiswa Aceh di kota Semarang yang pada hakikatnya merupakan individu - individu rasional dan kritis sebagai penilaian umum dimasyarakat, tentu ini harus relevan dengan apa yang telah menjadi teori pada kajian teori tipologi politik. Kenyataan yang ada dalam masyarakat adalah politik lebih berhak bagi mereka yang punya pengalaman dan mempunyai status sosial ekonomi yang cukup. Pendekatan psikologis, yang dikenalkan oleh sarjana IImu Politik dari Universitas Michigan, meliputi persepsi dan penilaian pribadi terhadap kandidat, persepsi dan penilaian pribadi terhadap tema-tema yang diangkat; dan identifikasi partai atau partisanship (Emilia \& Ichwanuddin, 2015:120). Pendekatan tersebut sangat menentukan pilihan seseorang. Sebanyak 17 narasumber yang diwawacara, ada 12 orang yang menyalurkan suaranya dan 5 memputuskan tidak memilih pada pemilu priseden 2019.

Demokrasi menggariskan bahwa pemilu adalah kesempatan bagi partai oposisi dan rakyat untuk menjalankan mekanisme check and balances terhadap partai yang berkuasa (ruling party). Meski banyak kalangan menilai konsepsi demokrasi seperti ini cenderung minimalis, namun praktek demokrasi yang minimalis tersebut telah 
membentuk sebuah sistem penentuan/pengisian jabatan-jabatan publik di semua negara demokratis. Artinya bahwa pemilu telah terlembaga secara institusional dan menjadi mekanisme universal dalam sistem politik di negara-negara demokratis (Dahl, 1990:6-7). Pilihan sesorang dalam memutukan ikut serta dalam pemilu sangat dipengaruhi lingkungan. Mahasiswa Aceh meengalami situasi berbeda pilihan politik dari mahasiswa yang berada di Asrama Aceh. Menurut informarman perbedaan pilihan sangat berpengaruh dalam kehidupan sehari-hari, namun perbedaan pandangan tidak menimbulkan gesekan sosial dan menumbuhkan daya kritis mahasiswa tentang program kerja yang dijanjikan pasalon.

"Perbedaan pilihan politik mempengaruhi kehidupan mahasiswa di Asrama Aceh, dengan pengaruh paling besar berupa candaan slogan atau program masing2 paslon kepada pendukungnya. Sumber: wawancara, (2019).

Bagi mahasiswa beselisih paham dan perbedaan pendapat menjadi sesuatu lumrah dalam kehidupan berpolitik, namun tetap menghargai pilihan. Hal tersebut dipertegas Roby Maulana Berutu.

"Perbedaan pilihan politik mempengaruhi kehidupan mahasiswa di Asrama Aceh, tapi kita tetap menghargai pilihan satu sama yang lain. Ya memang sedikit terjadi adu argumen dan pendapat. (Sumber: Wawancara.2019).

Perbedaan pilihan didasari pada penilaian objektif dan fakta calon. Diskusidiskusi mengenai perbedaan pilihan sering dilakukan dengan mengendepankan intelektual. Menurut informan Ikhsan Nugraha yang mempertegas pilihannya menyebut ketidakpuasan pemimpin sebelumnya menjadi dorongan memutuskan memilih salah satu calon. Dukungan salah satu calon dinilai bentuk demokrasi yang sehat karena mampu memberikan arguman terbuka yang mampu membuat partisipasi dan antusiasme meningkat.

"Karena saya merasa sangat tidak puas atas kinerja dari Presiden sebelumnya dan saya merasa pasangan Prabowo-Sandi lebih baik daripada pasangan Jokowi-Ma'ruf. Saya merasa perbedaan pilihan yang terdapat di lingkungan Asrama sangat baik. Hal tersebut bentuk dari wujud sistem demokrasi di Indonesia. Karena adanya perbedaan maka ruang diskusi menjadi terbuka", (sumber:wawancara, 2019)

Menurut Edmund Burke aktor yang terpilih untuk menjadi bagian dalam lembaga perwakilan, tidak hanya mewakili konstituen mereka. Mereka memiliki tanggung jawab untuk mewakili kepentingan masyarakat luas dan bukan segelintir pihak (Bachtiar, 2014). Berbeda dengan informan Ikhsan Taroki yang memilih pemimpin sebelumnya didasari pada faktor kepemimpinan yang membuat Indonesia maju dengan indikator pembangunan infrastruktur yang meningkat. Karater Jokowi sebagai pemimpin sederhana mencerminkan kepedulian terhadap masyarakat menengah kebawah.

"Saya memilih pasangan urut 01 Jokowi-Ma'ruf karena saya yakin dibawah kepemimpinan Presiden Jokowi Indonesia bisa menuju menjadi negara maju. Pembangunan yang paling menonjol yang dapat kita lihat adalah pembangunan di sektor insfrastruktur mulai dari jalan nasional, jalan tol, bandara, pelabuhan, 
waduk dan infrastruktur lainnya yang membawa Indonesia menuju negara maju", (Sumber:wawancara:2019).

Perbedaan pilihan di lingkunagn Asrama Aceh tidak terlalu mempengaruhi perilaku masing-masing mahasiswa dalam bergaul dengan teman-temannya. Walaupun terdapat beda pendapat dilakukan dengan mengandalkan pikiran logis dan tidak berpengaruh terhadap kehidupan pertemanannya. Dinamika dalam Pilpres dalam menyikapi perbedaan pilihan bukanlah sebuah permasalahan antar mahasiswa, dan hanya digunakan untuk memeriahkan Pilpres dan menjalin keakraban dengan penghuni asrama lainnya. Mahasiswa Aceh sangat mengedepankan kekeluargaan dan kedewasaan dalam menghargai perbedaan. Bentuk bereda pendapat lebih diutarakan berdasarkan kinerja dan program calon presiden.

Semangat demokrasi menuntut ruang partisipasi yang luas dan telah mengkonstruksi sistem demokrasi kita pada demokrasi langsung dimana rakyat secara langsung berpartisipasi untuk menentukan pilihan politiknya tanpa diwakilkan. Pelaksanaan pemilihan secara langsung dalam demokrasi modern bukan sekedar prosedur melainkan juga suatu keharusan untuk memperbaiki dan mengoreksi kesalahan dalam pelaksanaan pemerintahan. Pada titik ini konsepsi universalitas individu dalam demokrasi (memiliki hak yang sama) harus dijunjung. Semua warga negara memiliki peluang dan kesempatan yang sama dalam mengevaluasi dan menentukan pemimpinnya melalui partisipasi politik, sehingga keikutsertaan warga negara dalam pemilu menjadi penting. Pemahaman yang baik terhadap peran-peran strategis warga negara akan mendorong kualitas demokrasi. Setiap warga negara berhak dan wajib untuk berpartisipasi dalam setiap aspek kehidupan dan bernegara. Partisipasi warga negara dapat mencakup seluruh aspek kehidupan, tidak terkecuali dalam kehidupan politik. Mahasiswa Aceh sangat aktif dalam mendiskusikan politik yang diekspresikan dalam kehidupan sehari-hari, hal ini dipertegas Informan Darnivus.

Saya menyikapi perbedaan pilihan di lingkungan Asrama Aceh dengan obyektif, sesuai fakta tanpa mengecilkan pilihan yang lainnya. Pergaulan kita juga tetap baik, karena kita semua intelektual, maka kita berdiskusi secara profesional tanpa merendahkan salah satu pilihan. Sedangkan perilaku dari masing-masing kelompok, kita ekspresikan dengan game, misal dari sport, kita main futsal, tim Prabowo vs tim Jokowi. Semua kita lakukan dengan natural dan santai sebab kita tahu setiap pribadi punya pandangan masing-masing. (Sumber:wawancara:2019)

Pemilihan presiden dan wakil presiden pada pemilu tahun 2019, sebagai mahasiswa dengan asumsi penilaian rasional dan kritis terhadap kandidat pilpres terjadi penyamarataan antar masing-masing mahasiswa Aceh di kota Semarang yang berpartisipasi pada pemilihan umum tahun 2019. Temun dilapangan mahasiswa Aceh di kota Semarang rata-rata berada pada tipologi rasional, dengan penjelasan hampir semua responden yang memberikan keterangan menyampaikan bahwa dalam pemilihan presiden dan wakil presiden tidak ada anjuran dari orang tua untuk memilih kandidat tertentu. Pengaruh kandidat didasari pada tawaran program kerja yang meliputi peningkatan kesejahteraan sosial. Pertimbangan utama pilihan mengenai rekam jejak kandidat. Rekam jejak memberikan dampak positif menentukan pilihan sehingga penilaian figur semata yang berhubungan dengan masalah etnisitas, agama atau sara 
serta kedekatan emosional dengan mahasiswa itu sendiri. Menurut Informan Agung keputusan memilih berdasarkan penilaian kinerja dan rekam jejak.

Alasan pertama karena melihat kinerja jokowi pada periode 2014-2019 begitu banyak masalah yang terjadi dan tidak pernah ada jalan keluar untuk menyelesaikan berbagai masalah yg sedang dihadapi oleh Indonesia. Selain itu menurut saya pemilihan Ma'ruf Amin sebagai wakil presiden sangat sangat tidak cocok jika melihat berbagai masalah yang sedang dihadapi, atau bisa dikatakan tidak kapabel. (Sumber:wawancara)

Pemilihan berkualitas harus memiliki kriteria yang memberikan kesempatan meliputi memilih antara tawaran kebijakan yang berbeda. Meminta pertanggungjawaban pejabat terpilih untuk tindakan yang mereka lakukan dan mentranformasikan konsepsi simbolik (kedaulatan rakyat) dalam tindakan riil yang sesungguhnya ( Alemika dalam Liando, 2016:17). Penilaian tersebut mendorong orang terlibat. Pengaruh yang lebih konkrit terhadap penentuan pilihan politik pada pemilihan presiden didasari pada posisi kandidat cukup berpengaruh pada suatu kelompok atau komunitas, kedekatan emosional yang sangat erat. Pilihan politik mahasiswa didasari keterikatan golongan atau komunitas, balas budi atau balas jasa, sampai pada hal yang paling dekat yaitu adanya anggota keluarga yang mencalonkan diri sebagai anggota legislatif pada pemilu serentak tahun 2019. Namun tipologi tersebut tidak dalam konteks nasional yang menentukan pilihan mahasiswa Aceh.

Pemilihan umum pada 2019 terjadi fluktuasi pada tipologi pemilih mahasiswa pada level nasional tipe rasional dan kritis menjadi dasar penentuan pilihan politik mahasiswa. Namum pada level daerah, rasionalitas dan nalar kritis mahasiswa Aceh di kota Semarang bukan menjadi domain utama dalam penentuan pilihan politik, tapi lebih mengarah kepada faktor lingkungan (keluarga, kelompok dan kepercayaan). Mahasiswa Aceh yang notabenya berasal dari mayoritas muslim lebih condong memilih pemimpin berdasarkan kepercayaan. Drongan ini terlihat dari penilain kandidiat tanpa melihat kinerja.

Perilaku politik memberikan beberapa pemahaman tentang hubungan antara tindakan politik seorang dan sebuah proses politik dalam suatu sistem demokrasi. Tujuan utama dari mengetahui tentang perilaku politik adalah untuk menjelaskan apakah perilaku seorang pemilih dapat dikatakan netral atau tidak (Eesuola, 2013:5). Perilaku pemilih seseorang dapat dipengaruhi oleh sikap seseorang yang terbentuk melalui sosialisasi panjang dari latar belakang keluarga, maupun lingkup pekerjaan, agama, atau kegiatan-kegiatan dalam kelompok formal dan informal. Sikap seseorang tersebut akan memberikan pemahaman terhadap isu kebijakan dan kandidat. Sikap politik seseorang terhadap objek politik yang terwujud dalam tindakan atau aktivitas politik merupakan perilaku politik seseorang. Menurut Sastroatmodjo (1995:8) menyatakan perilaku politik adalah tindakan yang dilakukan oleh pemerintah ataupun masyarakat berkaitan dengan tujuan dari suatu masyarakat, kebijakan untuk mencapai suatu tujuan, serta sistem kekuasaan yang memungkinkan adanya suatu otoritas untuk mengatur kehidupan masyarakat kearah pencapaian tujuan tersebut. Mahasiswa Aceh tergolong kelompok yang telah memiliki sikap plihan baik didasari pada kepercayaan, konerja maupun berdasarkan komunitas. 


\section{Faktor Yang Mempengaruhi Partisipasi Politik}

Salah satu wujud pelaksanaan negara yang demokratis adalah dengan pelaksanaan Pemilihan Umum (Pemilu). Pemilu sebagai sarana demokratisasi telah digunakan di sebagian negara tidak terkecuali Indonesia yang nota bene memiliki masyarakat yang heterogen (Eta Yuni Lestari, 2018:65). Kepercayaan dan harapan dalam pemilu mendorong orang melakukan partisipasi.

Mahasiswa Asal Aceh Di Kota Semarang Pada Pemilihan Presiden Tahun 2019 memiliki penilaian atau alasan yang menjadikan menentukan pilihan politiknya. Kecenderung pada tipologi pemilih rasional pada level pemilihan Presiden sangat ditentuhnya kondisi psikologi. Pilihan politik tersebut di pengaruhi oleh beberapa Faktor, diantaranya adalah :

\section{Faktor Kognitif}

Mahasiswa Aceh mengedepankan analisis yang cukup radikal dalam penilaian kinerja maupun pencanangan dan perencanaan program kerja dari parpol atau kandidat yang mencalonkan diri pada pemilu. latar belakang golongan milenial yang mendapatkan informasi secara terbuka mendorong terjadinya proses pertukaran informasi dengan cepat. Sebut temuan Loina dan Zainal (2018) media sosial juga saat ini menjadi sumber rujukan berita dan informasi politik bagi mereka.

Menurut Informan M Risky penilaian kandidat berdasarkan argumen yang jelas mengambarkan keunggulan calon. Penilain tersebut didasari pada banyaknya Informasi berpengaruh berfikir rasionalitas dan keritis

Saya cenderung berlaku adil dalam perbedaan pilihan, saya mendukung argumen yang logis dan masuk akal, dan saya menolak argumen yang tidak masuk akal. Saya kadang suka beradu argumen, tapi hanya sekedar untuk canda candaan saja, tidak terlalu dianggap serius. Perbedaan pilihan politik sedikit banyak mempengaruhi kehidupan. (Sumber:wawancara,2019).

\section{Faktor Kandidat}

Penilaian mahasiswa Aceh terhadap kandidat dilihat dari melihat pada sisi penawaran program kerja, atau sisi kinerja pada periode sebelumnya. Pada pemetaan tipologi pemilih diatas kualitas figure merupakan salah satu penilaian yang mempengaruhi pilihan. Rekam jejak mulai dari pengalaman dan kinerja seorang kandidat menjadi salah satu variable penilaian mahasiswa dalam menetukan pilihan. Hal ini dipertegas Informan Ikhsan.

"Hal lain yang paling membuat saya memilih Jokowi disebabkan karena sosok beliau yang begitu hamble dan begitu peduli kepada masyarakat terutama masyarakat kalangan bawah", (Sumber:wawancara:2019).

Berbeda dengan informan Agung, penilai rekam jejak menjadi evaluasi dan menjadi dasar menentukan dukungan. Alasan kerja yang kurang maksimal mendasari pilihan.

Prabowo memang sudah berkali-kali kalah dalam proses pemilu, namun kita bisa melihat bahwasanya beliau adalah orang yg tidak pantang menyerah dalam berjuang, dan sosok sandiaga uno yg dipilih sebagai wakil menurut saya bisa 
menjadi jawaban bagi masalah ekonomi yg sedang dihadapi oleh Indonesia.(Sumber: Wawancara, 2020).

\section{Faktor Orangtua atau Keluarga}

Penentuan pilihan politiknya tipe ini dipengaruhi oleh kedekatan sosial budaya, kesamaan paham dan agama. Tipe pemilih seperti ini tidak mengedepankan aspek rasionalitas dan kekritisan dalam menentukan pilihan politiknya, sehingga jika ditinjau dari kelompok mahasiswa faktor ini terjadi karena dipengaruhi oleh kedekatan emosional, hubungan keluarga terutama intervensi orang tua dengan latar belakang pendidikan yang rendah. Mahasiswa Aceh pada dasarnya memiliki ruang lingkup literasi yang mendukung pilihan politiknya, namun masih ada mahasiswa dipengaruhi oleh kedekatan emosional dan pengaruh langsung.

Pada pemilu tahun 2019, media massa selalu memperlihatkan pertarungan dari pemilihan presiden dan wakil presiden, sehingga pada pemilihan DPRDKabupaten/kota, mahasiswa lebih mengedepankan tipologi tradisional dalam menentukan pilihan politiknya. Perilaku pemilih seseorang dapat dipengaruhi oleh sikap seseorang yang terbentuk melalui sosialisasi panjang yang dari latar belakang keluarga, maupun lingkup pekerjaan, agama, atau kegiatan-kegiatan dalam kelompok formal dan informal. Sikap seseorang tersebut akan meberikan pemahaman terhadap isu kebijakan dan kandidat.

Sikap politik seseorang terhadap objek politik yang terwujud dalam tindakan atau aktivitas politik merupakan perilaku politik seseorang. Mahasiswa Aceh menjadikan isu kebijkan menjadi dasar penentuan dalam pilihan.

\section{Faktor Penghambat Partisipasi Politik}

Faktor utam yang menghambat partisipasi politik pemilih yaitu kesibukan kegiatan sehari-hari para pemilih umumnya adalah pelajar, mahasiswa dan pekerja. Hal yang sangat wajar bagi para pemilih yang rata-rata umurnya berkisar 17-21 tahun itu. Mahasiswa perantuan ketika ingin menyuarakan suara harus menguruh surat terlebih dahulu bebrapa hari sebelum pemilihan, sehingga membutuhkan waktu lebih untuk mengurusnya.

Berkuliah dan bekerja menjadi alasan utama bagi para pemilih enggan melakukan kegiatannya dibidang politik terutama pemilu. data menunjukan dari 17 informan terdapat 5 orang yang memutuskan tidak memilih. Umumnya mereka tidak mau berurusan dengan berkas yang membutuhkan waktu lam. Informan Zubali menyebut ketidaktauan informasi dan waktu yang terbatas menjadi faktor utama tidak berpartisipasi dalam memilih.

"repot urusanya harus ngurus ini itu, aku kurang tau kapan ngurusnya ada yang bilang udah ditutup, terus nunggu juga bisa milih jam 12, lya kalau kebagian suara." (Sumber:wawancara, 2019).

Selain faktor berkas admistrasi, yang didasari bukan pada kemapuan dan pendidiakan, melainkan dan gender. Mahasiswa yang bergender perempuan memilliki partisipasi rendah karena pengurusan pemberkasan menjadi persoalan utama. Menurut Mohtar Mas'oed (2008) disamping pendidikan dan sosial ekonomi perbedaan jenis kelamin juga mempengaruhi keaktifan seseorang berpartisipasi dalam politik. Misalnya, laki-laki lebih aktif berpartisipasi dari pada perempuan, orang yang berstatus sosial 
tinggi lebih aktif dari pada berstatus sosial rendah (Sukma \& Wardhani, 2018:61). Menurut, Milbrath (Maran, 2007) menyebutkan tiga faktor panghambat suatu partisipasi politik mulai dari kebijakan induk organisasi selalu berubah, pemilih pemula yang otonom, dan dukungan yang kurang dari induk organisasi dalam rangka menyukseskan kegiatan politik (Febriantanto, 2019:167).

Mahasiswa Aceh sangat merasakan hambatan dari persoalan kebijakan yang dinilai memberatkan dan termasuk kedalam golongan pemilihan pemula yang perlu diberi sosialiasi informasi lebih. Menurut Myron Weiner seperti dikutip oleh Mas'oed, ada lima timbulnya gerakan kearah partisipasi lebih luas dalam proses politik, salah satunya pengaruh kaum intelektual yang memberikan pengaruh dalam berpartisipasi (Rio dkk, 2014:498). Namun hal tersebut menjamin setiap orang menyalurkan suara dalam pemilu temasuk sebagain kecil mahasiswa Aceh.

\section{SIMPULAN DAN SARAN}

Partisipasi politik mahasiswa asal Aceh di Kota Semarang pada Pemilihan Presiden Tahun 2019 memiliki partisipiasi baik yang direperesentasikan dalam penilaian kandidat berdasarkan kinerja dan rekam jejak. Hal tersebut mendorong terjalinnya diskusi-diskui dalam menyampaikan pendapatnya dan terjadi dinamika pilihan yang tidak mempengaruhi keputusan. Partisipasi mahasiswa Aceh tegolong dalam tipologi pemilih realsional dan keritis yang ditandai dengan kemapuan menilai kandidat berdasarkan fakta objektif.

Keputusan memilih kandidat disalurkan dalam pemilihan umum yang menandai orang melakukan penelitian. Sementara iti, faktor yang mempengaruhi partisipasi politik mahasiswa asal Aceh di Kota Semarang pada Pemilihan Presiden Tahun 2019 adalah faktor kognitif yaitu kemampuan mahasiswa asal Aceh dalam berpikir secara rasional dan kritis. Faktor kandidat dimana mahasiswa asal Aceh memilih kandidat yang memiliki karisma dan pengalaman yang baik dan faktor orang tua atau keluarga dimana pemilihan ini mengikuti dari pilihan orang tua. Faktor hambatan terjadi karena keterbatasan waktu pengurusan berkas acara agar dapat melaksanakan pemilu. penelitian kedepan menarik untuk melihat bagaimana pendidikan politik yang didapat mahasiswa dalam meningkatkan partipasi politik.

\section{DAFTAR PUSTAKA}

Bachtiar, F. R. (2014). Pemilu Indonesia Jurnal Politik Profetik Volume 3 Nomor 1 Tahun 2014. Jurnal Politik Profetik, 3.

Bisri, A. Z. (2011). PARTISIPASI POLITIK DALAM KETERBUKAAN INFORMASI PUBLIK Studi Kasus Interaksi Pattiro dengan Pemerintah Kota Semarang. Ejurnal.Undip.Ac.ld.

Dahl, R. A. (1990). Polyarchy: participation and Opposition. New Haven: Yale University Press.

Eesuola, K. (2013). Course Title: Political Behaviour. Victoria Island: National Open University of Nigeria.

Emilia, R. R., \& Ichwanuddin, W. (2015). POLITICAL PARTICIPATION AND VOTING BEHAVIOR IN GENERAL ELECTION 2014. 117-135.

Eta Yuni Lestari, N. A. etayuni@mail. unnes. ac. i. (2018). PARTISIPASI POLITIK PEMILIH PEMULA PADA PEMILIHAN WALIKOTA SEMARANG DI KOTA 
SEMARANG Eta. Integralistik, (1), 63-72.

Febriantanto, P., Disabilitas, P., \& Yogyakarta, K. (2019). Analisis Faktor Determinan Peningkatan Partisipasi Politik Penyandang Disabilitas pada Pilkada Kota Yogyakarta 2017. I(1), 157-190.

Harahap, R. R. (2016). PERILAKU POLITIK MASYARAKAT DALAM PEMILIHAN UMUM (PEMILU) LEGISLATIF KABUPATEN (Studi Kecamatan Dayun, Dapil II Kabupaten Siak, Tahun 2014). Jom FISIP, 3(2), 1-14. https://doi.org/10.1017/CBO9781107415324.004

Liando, D. M. (2016). PEMILU DAN PARTISIPASI POLITIK MASYARAKAT ( Studi Pada Pemilihan Anggota Legislatif Dan Pemilihan Presiden Dan Calon Wakil Presiden Di Kabupaten Minahasa Tahun 2014 ). 3, 14-28.

Loina Lalolo Krina Perangin-angin, dan M. Z. (2018). Partisipasi politik pemilih pemula dalam bingkai jejaring sosial di media sosial. Jurnal Aspikom, 3(4), 737-754.

Mas'udi, M., Qodarsasi, U., \& Dewi, N. R. (2018). Perilaku Partisipasi Pemilih pada Pemilihan Kepala Daerah Kabupaten Kudus Tahun 2018. JSW: Jurnal Sosiologi Walisongo, 2(2), 169. https://doi.org/10.21580/jsw.2018.2.2.3038

Newman, B. I., \& Sheth, J. N. (1985). A Model of Primary Voter Behavior. Journal of Consumer Research, 12(2), 178. https://doi.org/10.1086/208506

Rio Sholihin, Nur Fitriyah, S. M. (2014). Partisipasi Politik Masy arakat Dalam Pemilihan GubernurProvinsi Kalimantan Timur Periode Tahun 2013-2018 Di Kecamatan Sungai Pinang Kota Samarinda. Jurnal Administrative Reform, 2(4), 495-505.

Sastroatmodjo, S. (1995). Perilaku Politik. Semarang: Ikip Semarang Press.

Sukma, P., \& Wardhani, N. (2018). Partisipasi Politik Pemilih Pemula dalam Pemilihan. Jurnal Pendidikan IImu-IImu Sosial, 10(1), 57-62.

Undang-Undang Republik Indonesia Nomor 3 Tahun 1999 Tentang Pemilihan Umum. 